\title{
Shakespeare Translated by a Woman: Giustina Renier Michiel's Othello
}

\section{Eleonora FOIS*}

The same metaphors are employed to describe translation and women: they are defined, as Florio did, in terms of imperfection and inferiority, both deprived of creativity and of writing talent. Women's translation has been discussed by gender studies and translation studies: the analysis of women's translation helps to determine their motives, interests and strategies, and it is essential to balance the marginal position of women's writing in the history of literature. There is a vast body of literature analyzing the way Shakespeare interpreted and described women, but studies dealing explicitly with women translating Shakespeare are scarce. In Italy, women's translation played a crucial but overlooked role in Shakespeare's reception. Thus, this paper intends to focus on the first Italian translation of Othello by Giustina Renier Michiel, who was also the first and only woman translator of Shakespeare in Italy until the Fascist era. An exploration of Shakespeare's reception and an overview of female writing in Italy will introduce a contrastive analysis which aims at understanding Renier Michiel's translating approach and strategies. The goal is to highlight her personal input and to prove that her work, stained by a genderbiased judgment and critically downplayed as a mere indirect translation of Shakespeare's plays through Le Tourneur's French edition, was far more independent than believed.

Keywords: women's translation; history of translation; Shakespeare in Italy; Shakespeare in translation; Othello

\section{Introduction}

The discourse on women's translation used to pivot around two notions: imitation and inferiority. Jacques Peletier du Mans's (30) submission metaphor framed translation as a passive operation and reduced the target text to a pale copy of the original. Reinforcing such idea, John Florio ${ }^{1}$ equated translation with women: both lack creativity and writing talent and are defined in terms of imperfection and inferiority.

'Eloquent' is also the enduring metaphor according to which the source text is illicitly owned, twisted and corrupted by the translator. Translation becomes a form of betrayal. The

\footnotetext{
${ }^{*}$ Research fellow at Università di Cagliari.

E-mail: eleonora.fois@unica.it; ORCID ID: https://orcid.org/0000-0001-7802-6233.

(Received 16 October 2019; accepted 15 December 2019)

1 "Florio's Preface" to Montaigne's Essays translated by John Florio, accessed October 16, 2019, http://www.luminarium.org/renascence-editions/montaigne/\#p1.
} 
seventeenth-century metaphor of les belles infideles, in turn, unmasked the utopia behind translation as both aesthetically satisfying and reminiscent of the source text. It is the confirmation that writing is a male-dominated territory, and authorship, as the manly generative act, is the only assurance of authenticity. Furthermore, the reference to infidelity suggests sexual implications (Calvani 2012) and moral responsibilities, easing the comparison with women. Translation becomes implicitly gendered (Bassnett 2005, 89).

Despite this discouraging background, women translators shaped the contemporary literary debate as much as men, controlling and adapting the cultural exchange and the outer and inner solicitations (Semenenko 2012, 140). ${ }^{2}$ In Renaissance England, for instance, a new literary fashion was initiated by Margaret Tyler's translation of the Spanish romance by Diego Ortúñez de Calahorra (Roberts 2017). Through her translation of $A$ Discovery of New Worlds, Aphra Behn discussed scientific matters and challenged the women's established areas of competence (Todd 1993, 72). In eighteenth-century Italy, Giustina Renier Michiel actively contributed to the knowledge of Shakespeare thanks to her translations.

As highlighted by both translation studies and gender studies, translation was a means for women to develop their individuality and self-worth against the constraints of the patriarchal society (Baer and Massardier-Kenney 2015, 88). For women, translation became "a reconstructive process of mediated alterity" (Barker 2011, 61), which allowed them to empower themselves by experiencing the foreign. It is for this reason that, as Bassnett argues, the process is as important as the product: "[it] will always involve negotiation, rewriting and personal self-exploration" $(2005,87)$. Since the translator's stance and ideology inevitably filter through the text, ${ }^{3}$ the analysis of women's translation balances the marginal position of women's writing in the history of literature and helps to determine women's motives, interests and strategies, filling a cultural and literary gap.

Shakespeare was initially known in Italy through indirect translations (Hoenselaars 2003, 648). Before Pierre Le Tourneur, the source texts which introduced the Shakespearean

\footnotetext{
${ }^{2}$ The connection between cultures was synthesized by Lotman's notion of semiosphere ("The semiotic space necessary for the existence and functioning of languages" [Lotman 1990, 123]) and by the dichotomy inside/outside and we/the other (Mandelker 2006, 61) as the center of cultural acknowledgement. The survival of semiospheres depends on their ability to renovate and to keep communication open, but at the same time, they tend to be conservative: a dominant position fossilizes, while other subversive forces push to come to the surface.

${ }^{3}$ Ideology is, as Van Dijk defined it, the knowledge, beliefs and value systems of the individual and the society in which he or she operates (quoted in Munday 2007, 196).
} 
works in Italy were the French translations by La Place and Ducis. Defined as "very free renderings" (Petrone Fresco 1993, 111), they prevailed also on the Italian stage for a long time. Then Pierre Le Tourneur's Shakespeare traduit de l'anglais (Shakespeare translated from English), published in 1776 as a set of 20 volumes and dedicated to King Louis XVI, soon became the standard and remained the only complete version of Shakespeare's theatre until well on into the nineteenth century (Cushing 1908, 349).

Moreover, translating Shakespeare in Italy was prevalently a task for men. Antonio Conti's Il Giulio Cesare dates back to 1705. Another Giulio Cesare translated by Domenico Valentini-who admitted his lack of knowledge of the English source language - came out in 1726, with little critical praise (Graf 1911, 327). Alessandro Verri translated Hamlet (in an 8year span, from 1769 to 1777) and Othello (which was begun and completed in 1777) for a supposedly intellectual delight (Petrone Fresco 1993, 112), but the manuscripts were never published. ${ }^{4}$ Giulio Carcano's neoclassical translations came out between 1875 and 1882 . In the twentieth century, Shakespeare's plays were translated by Nobel Prize winners Salvatore Quasimodo and Eugenio Montale, academics such as Alessandro Serpieri and Agostino Lombardo and stage directors such as Cesare Garboli and Luigi Squarzina.

Giustina Renier Michiel stands out as the first and only woman to have translated Shakespeare until the fascist era (Calvani 2010). Between 1797 and 1801, she translated Othello (twenty years after Verri, but her translation was the first to be published), Macbeth and Coriolanus. Renier Michiel's translations, however, were critically downplayed as indirect translations through Le Tourneur's French translations. The aim of the present contribution is to explore Reiner Michiel's translation approach and strategies as a woman translator with a focus on her Italian translation of Othello (1797). After an exploration of Shakespeare's reception and an overview of women's writing in Italy until the eighteenth century, a contrastive analysis inclusive of the English source text will be carried out so as to reveal Renier Michiel's translating strategies. ${ }^{5}$

\footnotetext{
${ }^{4}$ Many could be the reasons behind his drastic decision: according to Verri's biographer Antonio Maggi, Verri could have been discouraged by the publications of Le Tourneur's translations (Petrone Fresco 1993, 112) as well as the cold reception of his previous work, a translation of The Iliad (Crinò 1950, 66).

${ }^{5}$ To prevent ambiguity in interpreting the terminology available to describe the translation process, the terminology here employed to describe Renier Michiel's linguistic techniques is drawn from Malone (1988).
} 


\section{Shakespeare in Italy}

The development of Shakespeare's affirmation in Italy perfectly exemplifies the theories on cultural communication and translation. In the eighteenth century, when the hold of French theatre was still strong, the belief that "Anglicum est, non legitur" (If it is written in english, it must not be read, my translation; Rebora 1949, 213) guided the resistance towards the Bard and his language. Voltaire's critical opinions on the matter deeply shaped the initial reception of Shakespeare, ${ }^{6}$ and the fear of dramaturgical contaminations which could lead to alterations of the neoclassical model further slowed the process.

The first Italian thinker to mention Shakespeare was Antonio Conti, the famous eighteenth-century translator of Pope and Racine, who in a 1715 letter talked of Shakespeare as a new author, the Corneille of the English (Butterfield 2000, 54). The rupture with the Aristotelian units drew suspicion in a still strongly neoclassicist environment. The target culture was not ready to consider alternative models, especially when they included very explicit representations of "horror most violent and barbarous" (Graf 1911, 304; my translation). The "first serious and extensive critical study of Shakespeare in Italy" (Lombardo 1997, 455; my translation) ${ }^{7}$ came out in 1777. Giuseppe Baretti, director of $L a$ Frusta Letteraria and vigorous accuser of the Italian subjection to French neoclassic models, explained in Discours sur Shakespeare et Monsieur de Voltaire (Conversation on Shakespeare and Mr. Voltaire) how Shakespeare could be the ideal inspiration to reinvigorate drama. Probably reminiscent of his own experience as a translator of Corneille, Baretti was nonetheless persuaded that translating Shakespeare was an impossible task. Despite comparing the finished translation to a tempting golden prize, he declared he did not have the courage to embrace the challenge (Crinò 1950, 63).

Inspired by Madame de Stael's incitement to produce modern translations, Michele Leoni's translations of Shakespearean tragedies were published between 1819 and 1821,

\footnotetext{
${ }^{6}$ Voltaire's prejudice towards Shakespeare, guilty of shadowing Molière, produced heavily ideologized translations: according to Baretti "il n'a point traduit le Julius Ceasar de Shakespeare, il l'a assassiné" (Crinò 1950, 20; he did not translate Julius Cesar, he murdered it; my translation). D'Alembert said that Voltaire had not understood how to properly translate English into French (McMahon 1964, 25), while Crinò noticed that "Troppo palese è infine l'insistenza nell'esagerare in senso meschino i sentimenti dei personaggi. . . . Troppo palese è l'intenzione di renderlo agli occhi dei propri connazionali 'dégoutant et méprisable"' (Crinò 1950, 20; Too obvious is his insistence on exaggerating the characters' most hideous feelings, too obvious is his intention of making his fellow countrymen see Shakespeare as 'dégoutant et méprisable'; my translation).

${ }^{7}$ Baretti's interest in Shakespeare had already been made manifest in Dissertation upon the Italian Poetry (1753) and Dissertation upon the Italian Tongue (1757) (Lombardo 1964, 4).
} 
accompanied by Johnson's preface. Leoni's Otello, however, was still significantly influenced by the literary aesthetics of his time: he followed the Aristotelian units and simplified the action. Furthermore, the use of the verse, the tendency to elevate the register and the omission of inconvenient or problematic passages mirrored the still powerful neoclassic authority (Locatelli 1999, 28). Leoni's translation was the reference for the performances of Gustavo Modena, whose acting style was far removed from the declamatory custom of his time (Alonge 1998, 4). Modena's choice of performing Shakespeare was an attempt to revitalize the Italian theatre, which needed new plays and new approaches.

Carlo Rusconi's 1839 Othello abandoned verse for prose, in the belief that translating the poetry of the verse while reproducing sounds and style was impossible (Locatelli 1999, 27). He was also convinced that the alternation of verse and prose was a structural discontinuity related to Shakespeare's dissolute life instead of a precise stylistic choice. ${ }^{8}$

With both Leoni's and Rusconi's translations being as anticipated in approaching a relatively new author of uncertain fame and unfamiliar style, Renier Michiel's innovative contribution to the Italian literary development, as well as that of many cultured Italian women, has been lessened or even forgotten. ${ }^{9}$

\footnotetext{
8 "His style lacks in dignity-just like his life does" (Locatelli 1999, 32; my translation).

${ }^{9}$ Particularly indicative of women's status in the Italian editorial world and of the scarce progress made to this day by women translators is the case of Lucia Rodocanachi, the "shadow translatress" of Eugenio Montale (Contorbia 2006, 78), as it is revealed in the correspondence they kept for almost twenty years (April 1928December 1947). Montale himself labeled such collaboration as "scandalous" (Contorbia 2006, 60; my translation) due to the late recognition of her unpaid work, in an almost - if not definite - servile relationship: "una modalità ... destinata a ripetersi con altri futuri autori-traduttori, da Carlo Emilio Gadda a Camillo Sbarbaro" (a practice destined to be repeated with other authors/translators, from Carlo Emilio Gadda to Camillo Sbarbaro; Contorbia 2006, 60; my translation). Rodocanachi's involvement was necessary when Montale's poetic sensitivity did not match the source text, as in To a God Unknown by Steinbeck. Montale wanted from Rodocanachi a literal translation for him to refine, but (predictably) such method did not satisfy the poet: "your rhythm is so different than mine that, without fault from you, I end up redoing everything. We will have to devise another form of collaboration: I will send you the drafts so that you will be able to help me next time" (Contorbia 2006, 85; my translation). Montale never included a clear mention of Rodocanachi, as an exchange hypothesizing the translation of Green Mansions by Hudson proved: "we could translate between us, without mentioning it to anyone, and once the work is done we could sell it to Einaudi or some other publishing house with my name on it, of course" (Contorbia 2006, 90; my translation). Her work for Montale included To a God Unknown by Steinbeck, That Evening Sun by Faulkner, El Rajo de Luna by Gustavo Adolfo Bécquer, Greguerías by Ramon Gomez de la Serna, and short stories by Herman Bang and Bernal Diaz Castillo. Another translation, Richardson's Clarissa, was interrupted by Montale, dissatisfied with the payment (Contorbia 2006, 89). Collaborative translation is not unusual, and it is sometimes even encouraged. In this case, however, despite her eclecticism and cultural vitality, Rodocanachi could not find a place in that literary circle which was so eager to secretly benefit from her support, and her recent recognition is long overdue.
} 


\section{Women's Writing in Italy}

An overwhelming prevalence of male scholars emerges from this brief overview; women's writing in eighteenth-century Italy, however, was a growing reality. Given women's general illiteracy, the supremacy of Latin as a literary language precluded women's active participation in the cultural scene. The rise of the vernacular in the fifteenth century and the affirmation of the volgare as the ruling language in the late sixteenth century $(\operatorname{Cox} 2008,37)$ marked a new beginning. Isabella and Beatrice d'Este and Elisabetta di Montefeltro are examples of the rise of women's patronage, in turn encouraged by vernacular poetry, whose ideal audience mainly included women (40).

Between the fifteenth and sixteenth century, however, women's role was, with few exceptions, still largely representative. Ippolita Sforza Bentivoglio, dedicatee of Matteo Bandello's Novelle (Short stories), was described as an example of educated female reader and authoritative critic. In 1548, Laura Terracina published a volume of Petrarchan-inspired poetry displaying some feminist intentions and authorial consciousness, but her work was harshly dismissed by Benedetto Croce as dull and valueless (Waring 2007, 152).

The fame of women poets such as Veronica Gambara and Vittoria Colonna, referred to as the stars of the feminine Parnassus (Chemello 2010,49), encouraged women to pursue a literary career as a respectable goal (Cox 2008, 76). However, those who aspired to write in the eighteenth century still had to do so in secret (Russell 1997, 78). In this period, women's poetry managed to be more than an encomiastic or necessarily decorous production, dealing with socially significant themes. Maria Zappi wrote about the attempted rape she had faced and the loss of a child; Corilla Olimpica defended women's professional ambitions; Petronilla Paolini Massimi, Prudenza Capizzucchi and Faustina Maratti discussed marriage and conjugal love. In terms of themes, then, Italian women poets were very different from their British counterparts (Russell 1997, 79). Like for British women, however, translation represented a concrete intellectual chance for Italian women who aspired to discuss philosophical, literary, theological and historical issues. Luisa Bergalli, whose original plays were unrightfully underestimated in the history of Italian theatre (Steward 1994, 55), translated Racine, Molière (1736-45) and La Motte. In 1722, Giuseppa Eleonora Barbapiccola translated René Descartes's Principles of Philosophy. Her preface, which displayed those same modest tactics found in Early Modern women translations (Goodfellow 1996, 232), became a manifesto for 
women's emancipation (Messbarger and Finden 2005, 44). Giuseppa Eleonora Barbapiccola strongly advocated women's right to a meaningful education and proper consideration in a male-dominated intellectual discourse, mentioning eminent women thinkers such as Madame Dacier to support her argument (Russell 1997, 27).

Women were also involved in journalism: Caterina Cracas, Fanny Morelli and Eleonora de Fonseca Pimentel all curated their own journals and magazines (Russell 1997, 80). Eleonora de Fonseca Pimentel was also active in politics, believing that only education, as the solution to ignorance, could guide voters towards wiser political choices (Jones 2000, 129). Elisabetta Caminer Turra, who was mostly self-educated, employed the usual downplaying tactics to prevent criticism on the "paucity of her talent" (122) while pursuing her activity as a journalist and editor and exploiting her position to publish about women's issues.

Fighting ostracism and unfavorable conditions, these women challenged the literary prejudice of their time, as did Renier Michiel, the only Shakespearean translatress (with the exception of Carmelina Vittori's two acts from the Cymbeline in 1892) until the twentieth century. ${ }^{10}$

\section{Giustina Renier Michiel's Othello}

Giustina Renier Michiel was the first translator and the first woman to provide a full translation into Italian of three of Shakespeare's plays. Othello, Macbeth and Coriolanus were published between 1797 and 1801, with a significant omission: the translator's name. The cover of Othello merely mentions "a Venetian dame," as a clear sign of the scarce prestige of literary women translators. Renier Michiel was a woman of noble origins and privileged background (she was the daughter of an ambassador of the Papal court and niece of the Doge

\footnotetext{
${ }^{10}$ As an interpreter of the Roman history so dear to the Fascists, Shakespeare became an active feature of their propaganda. Some critics such as Piero Rebora wrote pages on Shakespeare's interpretation of politics, twisting his plays in the name of propaganda. Such renovated impulse to translate Shakespeare probably came also from the fascist educational campaign. The regime propaganda encouraged women to be involved in society as much and as intensively as men, at least apparently. As Margherita Armani wrote in Civiltà Fascista (Fascist civilization), women were encouraged to play their part in the life of the regime, but an active participation in political life was not included. They were expected and urged to promote the fascist values inside their homes, as careful keepers of the fascist roots (Calvani 2010, 8). The fascist propaganda gave the impression of empowering women by protecting their condition as mothers and wives, and this could explain the sudden emergence of women eager to promote and exalt that regime, which gave them a purpose. Between 1924 and 1925, three different editions of Coriolanus were published, all of them translated by women: Laura Torretta, Emma Boghen Conigliani and Ada Salvatore. Julius Caesar, The Tempest and Macbeth were instead translated by Bianca Avancini.
} 
Paolo Renier). She was cultured and had excellent acquaintances, such as Melchiorre Cesarotti, one of the most renowned men of that time.

The letter exchange between Renier Michiel and Cesarotti is of particular interest for the origin of Renier Michiel's translating project. Unfortunately, only Cesarotti's letters survived: those sent by Renier Michiel were burned on Cesarotti's request (Crotti 2005, 227). Although Malamanni, curator of the first collection of Cesarotti's letters, firmly denies it, the correspondence from Renier Michiel might have been destroyed to preserve Cesarotti's reputation (228), since women were seen as a constant menace to men's honor. This loss of crucial documents demonstrates the scarce importance assigned to women's literary and cultural contributions: Renier Michiel's direct account of the challenges of her task appears to be definitely lost. With the exception of her preface, her ideas are only available indirectly, through Cesarotti's replies.

As Alfieri wrote in his Vita, there was no other choice but to read Shakespeare in the 1776 French translation by Le Tourneur (Crinò 1950, 92). Renier Michiel then provided an alternative, vulgarizing some of the tragedies and widening the potential pool of readers. On the one hand, the documentation around Renier Michiel's translations is still quite vague and nebulous, making it challenging to understand the editorial diffusion of her translations. On the other, few doubts surround the critical reaction to her work, which was of cold indifference: Ugo Foscolo, despite owning his acquaintance with Shakespeare to Renier Michiel's translations (Locatelli 1999, 29), only briefly refers to her as 'the translatress,' without further details.

Such general indifference was probably motivated by the belief that Cesarotti was the mind behind the majority of the work. Vittorio Malamani, one of Renier Michiel's harshest critics, influenced all forthcoming studies when he claimed that Cesarotti's literary touch was felt throughout the translations, from the introduction to the critical notes (Calvani 2017, 125), heavily downsizing Renier Michiel's personal contribution. ${ }^{11}$ Melchiorre Cesarotti wrote about translation ${ }^{12}$ and attempted to put his theoretical ideas into practice by working on Eschilo, Voltaire, Demosthenes and Homer's Iliad, translated both in verse and in prose.

\footnotetext{
${ }^{11}$ What seems to be certain, however, is that Renier Michiel's rendition of the songs in Othello is based on an Ossianic fascination which comes from Cesarotti (Bianco 2017, 8).

${ }^{12}$ In Cesarotti's view, translation was supposed to unite two languages in one: following the highs and lows of the text, the good translator was supposed to soften the asperities of the source language and enrich the target language without violence (Laurenti 2015, 185).
} 
While Cesarotti the philologist showed great competence in the prefaces and the commentaries accompanying his works, Cesarotti the translator was not able to let his own style aside, often binding and suffocating the nature of the Homerian source text (Laurenti $2015,185)$. The upcoming analysis will prove that features of the Italian target text are not compatible with Cesarotti's translating style. Still, in 1916, Renier Michiel was described as a "careless and inaccurate writer" (Collison-Morley 1916, 76), which would have forced Cesarotti to correct most of her work: "Giustina Renier-Michiel did not know enough English to understand Shakespeare in the original and she merely translate[d] Le Tourneur" (77).

A closer look at her work demonstrates the inaccuracy of such judgment. The preface of Otello, for instance, was the result of excerpts and parts directly translated from Le Tourneur's preface (which already downplays Cesarotti's influence), with some original additions clarifying the purpose of her translation. As Renier Michiel claims in the "Prefazione della Traduttrice" (Preface of the translatress), Shakespeare's "affection and tenderness" (Renier Michiel 1797, 4; my translation) toward his women characters was readily acknowledged and appreciated by his women audience. Proving her familiarity with the literary debate concerning Shakespeare, she recalled that "English ladies were the first to pay a public tribute of honour and gratefulness to him" (6; my translation): she was probably referring to the Shakespeare Ladies Club, whose efforts were directed at rescuing Shakespeare's plays from oblivion. ${ }^{13}$

Renier Michiel sought the right balance between constraining fidelity and deforming freedom. Proving her acquaintance with the theories of her time, Renier Michiel supported her argument by quoting the French translator Pierre Brumoy ${ }^{14}$ (not mentioned in Le Tourneur). According to Brumoy, a translation has to avoid becoming "a wax portrait" (8; my translation), that is, so similar to the original that it becomes lifeless. Renier Michiel, however, believed the translation should sound natural in the target language. For this reason,

\footnotetext{
${ }^{13}$ Created towards the end of 1736, it surely featured Susanna Ashley Cooper, wife of the fourth earl of Shaftesbury, Elizabeth Boyd and Mary Cowper, who, together with other women, actively pressed London theatre managers to stage more Shakespeare plays (Kemp 2010, 120). "They have generously contributed to raise a Monument to his Memory, and frequently honour his Works with their Presence on the Stage:-An action which deserves the highest Encomiums, and will be attended with an adequate Reward; since, in preserving the Fame of the dead Bard, they add a Brightness to their own, which will shine to late Posterity" (Ritchie 2014, 147). Moreover, Renier Michiel's frequent mention of Lady Mary Wortley Montague in the preface of Macbeth proves her knowledge of the early British feminist movement (Calvani 2010, 6).

${ }^{14}$ In 1730, Father Pierre Brumoy published a monumental study of Greek drama: Le Théâtre des Grecs (Walton 2008, 269; The theatre of the Greeks), which Renier Michiel probably knew.
} 
she resigned to providing a direct and literal translation of "some peculiar lines" from the source text — the English source text — whenever the "genius of our language [Italian]" (1797, 9; my translation) called for it. The awareness of the distance between some lines of her translation and the source text already reveals that Pope's edition was among her references.

In the "Preface of the Translatress," Renier Michiel (1797) explicitly addressed and criticized society's expectations on the subjects suited to women.

Io sarei stata inclinata a premettere in questa prefazione generale le mie riflessioni sulle sensazioni che destano le rappresentazioni drammatiche. . . Q Questo è forse il solo argomento su cui una donna possa ragionare senza temer le accuse degli uomini. Ma non avrei potuto farlo fondatamente senza discutere quanto ne scrissero molti celebri Letterati; e forse questo non si sarebbe perdonato ad una donna. (9-10)

(I would have been inclined to insert some thoughts on the sensations provided by theatrical performances. .. . This may be the only subject women can discuss without fear of men's accusations. But I could not do it properly without mentioning the words of many illustrious intellectuals, and that would have been unforgivable for a woman; my translation)

She exploited the preface to speak openly about women's conditions. She also clarified her motivations, indirectly revealing the social system of that time:

M'accordino dunque i Lettori sensibili qualche indulgenza, se altra parte pretendere non potendo all'educazione delle mie tenere Figlie, apparecchio loro una lettura, che possa, quando che sia, e trattenerle ad un tempo e istruirle, e contribuire insieme alla loro felicità, regolando con gli esempi le loro nascenti passioni. (24)

(Given that I cannot aspire to be involved in my daughters' education, my Readers will be indulgent if I prepare for my daughters a reading which, in due time, might entertain them and educate them at the same time, so that I might contribute to their happiness by moderating their rising passions; my translation)

Despite her undisputable and central position as a cultural promoter in Venice, these words confirm that Renier Michiel was not allowed to be directly involved in her daughters' education. Hence, her translations aimed at filling that void by providing her daughters with both entertaining and thought-provoking readings. She wanted to teach them to control those passions which doomed Desdemona, Lady Macbeth and Volumnia while tracing a symbolic evolution of women's lives (Calvani 2017, 135). All the female characters of the selected tragedies share strength and initiative in taking control of their lives; however, their independence will be their doom. It is a message aligned with the idea of an obedient woman of careful behavior. Desdemona's example is clear: it was her independence in marrying 
Othello without accepting her father's guide which signed her demise. Lady Macbeth's dominant and aggressive attitude, more appropriate to a man than to a woman, succumbed to her feminine nature which could not stand the horror of her crimes. Similarly, Volumnia's ambition and thirst for power determined her son's defeat. The message of the translatress, who adheres here to the womanly image promoted by Mary Wollstonecraft (Calvani 2010, 5), is clear: women who cultivate manly traits, going against their nature, are doomed to fail.

"Vita di Shakspeare [sic]" (Life of Shakespeare), the section following the preface, begins with a brief original introduction by Renier Michiel. She stressed the importance of knowing the main biographical events of great artists' lives, not only as a tribute to their memory but also as a way of satisfying the readers' curiosity. The rest of the chapter is taken from Le Tourneur's "Vie de Shakespeare" (Life of Shakespeare), with some reductions ${ }^{15}$ (for instance, there is no mention of the heritage Henry VII gave to Shakespeare's family). The short story "Novella D'Ottello o sia Del Moro di Venezia" (Story of Othello or the Moor of Venice) by Giovan Battista Giraldi Cinzio (from the collection Ecatommiti, a hundred tales), introduced by Le Tourneur without any mention of its origin, is instead rich in details in Renier Michiel's edition (Renier Michiel 1797, 79). She probably found the introductory words of the short story fitting for her educational purpose: here, the author admits the frailty of both men and women in falling prey to passions. Women, however, especially married ones, should prefer death to the sin of their souls. Desdemona's words are particularly significant in this context: "da me le donne Italiane imparino, di non si accompagnare con uomo, cui la natura e il cielo e il mondo della vita disgiunge da noi" (70; Let Italian Women learn from me, not to choose a man whose nature, sky and world differ from ours; my translation).

Renier Michiel admitted having used Le Tourneur's French translation. Her desire to include a solid source of reference does not come as a surprise, given the originality of her task. Le Tourneur's translations, whose numerous notes clearly revealed a rigorous research, were a milestone in the history of Shakespeare in France. Still, despite Le Tourneur's good intentions, his eighteenth-century literary sensibility was far from Shakespeare's style and language. According to Crinò $(1950,95)$, Le Tourneur's translations are stylistically burdened by opaque adjectival choices, an excessive explicitness of allegories and a tendency to

\footnotetext{
${ }^{15}$ As her translation progressed, she abandoned her "French tutor" (Calvani 2017, 23) and felt more confident in her skills.
} 
lengthen the sentences and heighten the register. Renier Michiel's (1797) more direct and personal style emerged already from the "Vie de Shakespeare" section, where no trace remains of Le Tourneur's (1776) wordiness:

Le Tourneur: Le jeune Shakspeare revint modestement reprendre son rang parmi ses frères, \& oublier les premières leçons des Muses dans les arides \& pénibles details du négoce. (xi)

(The young Shakespeare modestly took back his place among his brothers: he forgot the first lessons of the Muses, lost among the dry and hard trade work; my translation)

Renier Michiel: Riprese egli interamente la maniera di vivere della famiglia. (27)

(He reprised his family's way of life; my translation)

This analysis, however, aims at demonstrating that Pope's English edition was also largely consulted. The differences between the French and the Italian target texts, in fact, demonstrate the status of Pope's edition as Renier Michiel's primary reference. Renier Michiel's strategy then included working with Le Tourneur's translations and Pope's English edition, to get closer to the original. In act 1, scene 1, for instance, Pope's edition presents: "I take much unkindly that thou, Iago, who hast had my purse as if the strings were thine, shouldst know of this" (Shakespeare 1768, 343).

Le Tourneur: Je trouve indigne à vous qui disposez de ma bourse, comme si les nœuds en étoient dans vos mains, vous, Jago, sachant ce qui se passait . . . (1776, 3-4)

(I find it despicable that you, who dispose of my purse as if it the knots were in your hands, that you, Iago, knowing what was going on . . .; my translation)

Renier Michiel: Tu Jago, che disponi della mia borsa come della tua, come mai, sapendo una cosa tale . . . ? $(1797,85)$

(You, Iago, who dispose of my purse as if it was yours, how come that knowing such a thing. . . ?; my translation)

Renier Michiel kept the vocative in almost the same position as Pope's edition: in so doing, she preserved the context-creating function of deictics (Stavinschi 2012, 245) and shaped a natural line of spoken dialogue. She neutralized the simile, focusing only on its meaning, but she provided a direct translation of Roderigo's line in an endnote. ${ }^{16}$

In act 1, scene 1, Iago discusses Cassio's ignorance of the battlefield, noting: "nor the divisions of a battle [he] knows more than a spinster" (Shakespeare 1768, 344). Le Tourneur

\footnotetext{
${ }^{16}$ Renier Michiel $(1797,295)$. Her precision is mirrored in the numerous endnotes (12, 17, 18, 24, 29, 35, 42, 52, 62), which include the English verse along with its direct translation.
} 
$(1776,6)$ kept the reference to needlecraft but neutralized the comparative: "Qui ne connoît pas plus les divisions d'une armée, que celle dont la vie se passe entre la quenouille \& le fuseau" (He does not know the divisions of an army better than the difference between a distaff and a spindle; my translation). Renier Michiel $(1797,86)$ translated directly: 'Non conosce la distribuzione d'armata meglio di una filatrice" (He does not know the divisions of an army better than a spinster would; my translation). The fact that Renier Michiel often chose to stay closer to the English source text than to the French translation supports the hypothesis that the English source text was more than a sporadic reference.

Shakespeare's writing was carefully impregnated with meaning: every word in the text was there for a specific reason (Hulme 1962, 20). Shakespeare was able to be concise but precise and eloquent at the same time. Thanks to the reference to the English source text, Renier Michiel's translation managed to preserve this stylistic feature. This is particularly evident, for instance, in the translation of Cassio's line (act 2, scene 3), “. . And in terrestrial vesture of creation / do's bear all excellency" (Shakespeare 1768, 367):

Le Tourneur: . . . dans toutes les qualités, dans toutes les grâces dont l'a revêtue la nature, elle offre le modèle de toutes les perfections $(1776,56)$

(. . . of all qualities, of all gifts Nature has bestowed on her, she is a model of all perfections; my translation)

Renier Michiel: . . che raccoglie in sé sola tutte le perfezioni della Natura $(1797,131)$

(... that gathers in her all the perfections of Nature; my translation)

Unlike Le Tourneur, who amplified the line with a rhetorical device absent in the source text, Renier Michiel reduced and partially recategorized Cassio's line, presenting a somehow more direct translation in endnote $15 .{ }^{17}$ The same strategy and approach are found in act 3, scene 5, where Othello's line "excellent wretch" (Shakespeare 1768, 393) becomes:

Le Tourneur: Intéressante orpheline, naïve enfant, excellente créature! $(1776,116)$

(Interesting orphan, naïve child, excellent creature!; my translation)

Renier Michiel: Eccellente ragazza! $(1797,181)$

(Excellent girl!; my translation)

Le Tourneur retraced the meaning of 'wretch' as an ancient expression of tenderness and justified his choice in an explanatory footnote $(1776,116)$, but he amplified the line by

\footnotetext{
17 "e tra gli ornamenti della creazione ella merita il primo posto" (301; and among the ornaments of creation she deserves to be the first; my translation)
} 
adding two noun phrases. ${ }^{18}$ Renier Michiel kept the English adjective (economizing on words) but neutralized the noun, presenting the English verse along with Le Tourneur's explanation in endnote 27 (1797, 306-307).

The intention to provide a direct translation sometimes caused translation errors. In act 1, scene 1, Iago's reference “And I . . . must be let and calm'd / by debitor and credior" (Shakespeare 1768,344$)$ was translated by Le Tourneur $(1776,5)$ via substitution: "je me vois rebuté \& payé de vaines paroles" (I am repaid with vain words; my translation). Renier Michiel $(1797,86) \mathrm{kept}$ the reference to creditor and debtor discarded by Le Tourneur: "Devo essere posposto a questo calcolatore di puglie ${ }^{19}$, che non sa parlare che di debiti, e crediti nel giuoco!" (I have to make way for this chip-counter, who only talks about game debts and creditors; my translation). The misinterpretation of that reference, however, deviated the meaning of the verse. Another similar case is found again in act 1, scene 1: "It is as sure as you are Roderigo / Were I the Moor, I would not be Iago" (Shakespeare 1768, 345):

Le Tourneur: Comment vous vivez pour Roderigo seul, il est certain que si j'étois ${ }^{20}$ le More je ne voudrois pas vivre pour Jago. $(1776,6)$

(Just as you live for Roderigo only, it's certain that if I were the Moor, I would not want to live for Iago; my translation)

Renier Michiel: Se io mi trovassi nel caso del Moro, non opererei come opero. (1797, 88)

(If I was in the Moor's position, I would not act as I do; my translation)

The explanation in the footnote confirms that Renier Michiel clearly misunderstood the meaning of the line (1797, 296; "si deve con ciò intendere che le loro viste son diverse, diversa essendo la situazione d'Ottello da quella di Iago;" what needs to be understood is that their perspectives are different, being Othello's situation different from Iago's; my translation).

Despite some errors, Renier Michiel's conciseness ${ }^{21}$ was still closer to capturing the careful word selection of the source text than Le Tourneur's verbosity. Renier Michiel's

\footnotetext{
${ }^{18}$ A research on the origins of the word 'wretch' and its less frequent meanings cannot support Le Tourneur's justification.

${ }^{19}$ In Italian, a 'puglia' is a chip used in card games. Treccani, s.v. "pùglia," accessed December 20, 2019, http://www.treccani.it/vocabolario/puglia.

${ }^{20}$ Possible differences in the spellings of words relative to their current uses in French result from their appearance in the original work.

${ }^{21}$ Giuseppe Verdi understood how synthesis and proper lexical choices could make the difference in dramatic terms: during the preparation for his Macbeth, he insisted on the importance of writing "poche parole ... poche,
} 
attention to the style of the Shakespearean text, whose conciseness was oriented towards the actor's performance (Serpieri 1988, 14), is even more interesting considering that her objective was not to have her translation performed on stage.

The authority of Pope's English edition persuaded Renier Michiel (1797) to omit some lines of uncertain attribution (endnote 21,303$){ }^{22}$ However, some passages which feature in Pope's English edition do not appear in Renier Michiel's translation. These omissions can only be explained considering the function that the target text had to fulfill. Whenever the English source text presented contents and language deemed unfit for young women, Renier Michiel departed from the source so as to preserve the educative purposes of her translation. Shakespeare, in fact, played with different registers and did not refrain from using strong images and vulgar language. As Hamburger $(1994,127)$ noticed, contemporary translations struggle to preserve these features. Shakespeare's established canonical status encourages the tendency to elevate the register, and his verbal witticism is approached with alternating fortunes (Fois 2018, 149). It is then interesting to verify how Renier Michiel tackled these issues, considering the educational purpose underlying the translation, her cultural background which did not encourage nor support such language and society's expectations concerning the appropriate language for a woman.

The explicit image in the verses "Even now, now, very now, an old black ram / Is tupping your white ewe" (88-89; act 1 , scene 1$)$ was treated differently by the two translators. Le Tourneur $(1776,8)$ used the metaphor of a vulture devouring a dove ("un noir vautour se repait de vostre jeune \& blanche Colombe"; a black volture is feeding on your young and white dove; my translation), an image of aggression and violence far from sexuality. Renier Michiel $(1797,90)$ managed to find a way to moderate the expression without deviating completely from it: "Adesso, in questo punto istesso, un sozzo nero animale oltraggia la vostra candida agnella" (right now, right where we stand, a dirty black animal is abusing your pure lamb; my translation). The feminine noun agnella is a specifically literary term which probably aims at compensating the roughness of the source text by heightening the register: it accentuates Desdemona's (and women's in general) meekness and bashfulness. The verb

poche ma significanti" (Melchiori 2006, 101; few words ... few, but meaningful; my translation).

${ }^{22}$ According to Renier Michiel $(1797,303)$, they were from a popular English song whose translation would have been unsatisfactory: "perderebbero tutto lo spirito" (they would lose all their spirit; my translation). 
oltraggiare can mean 'to insult' but also 'to sexually violate': ${ }^{23}$ with a clear shift from Shakespeare's lines, Renier Michiel stressed the violation of a woman's virtue. Such a shift is probably the result of the moral boundaries which prevented her from encouraging the idea of a free, desire-driven sexual act.

In act 1, scene 1, "I am the one, sir, who comes to tell you, your daughter and the Moor are now making the beast with two backs" (Shakespeare 1768, 347), the explicit image is neutralized by Le Tourneur, but Renier Michiel goes further and omits even the allusion to a sexual encounter:

Le Tourneur: Dans les bras l'un de l'autre votre fille \& le More ne font qu'un. (1776, 10)

(in each other's arms, your daughter and the Moor are becoming one; my translation)

Renier Michiel: In questo momento istesso il Moro e vostra figlia sono insieme. (1797, 92)

(right now, the Moor and your daughter are together; my translation)

The intention of the translatress was clarified in endnote 5: "si eliminano qui, come in vari altri luoghi, molte indecenze" (Renier Michiel 1797, 296; here and elsewhere, many indecencies are erased; my translation). When said 'indecencies' were suited to her educational purpose, however, she opted for bolder solutions. In act 1, scene 1, Shakespeare employs another euphemism for a sexual encounter, describing Desdemona being transported “To the gross clasps of a lascivious Moor" (Shakespeare 1768, 347). This time Renier Michiel is more explicit:

Le Tourneur: Elle va offrir ses charmes aux profanes embrassements d'un Mor lascif $(1776,11)$

Renier Michiel: Condotta ai lascivi amplessi dello schifoso Moro $(1797,93)$

Le Tourneur translated 'profane embraces of a lascivious Moor', softening Shakespeare's image but keeping its nature. Renier Michiel abandoned the metaphor and translated 'clasps' as 'sexual intercourse.' Moreover, she redistributed the adjectives, referring to the sexual intercourse as 'lascivious' and adding the adjective schifoso (revolting, disgusting). Such lexical selection, clearly motivated by a manipulative intent, discloses Renier Michiel's ideology, which, in turn, confirms the educational nature of her target text.

\footnotetext{
${ }^{23}$ Treccani, s.v. "oltràggio," accessed December 20, 2019, http://www.treccani.it/vocabolario/oltraggio.
} 
The omissions include puns and wordplay, which are features of Shakespeare's writing style that challenge even contemporary translators. Considered fairly marginal in the overall harmony of the play, puns are often ignored altogether or selected giving preference to the ones with minor diachronic interference (Quasimodo et al. 1964, 19). Renier Michiel and Le Tourneur's strategies are, in this case, perfectly aligned in erasing the creative uses of language of the source text. Suffice it to mention the dialogue between Desdemona and the Clown at the beginning of act 3, scene 9 (Shakespeare 1768, 405). The puns pivoting around the verb 'to lie' were entirely omitted by both Le Tourneur, who did not provide any explanation and did not warn his readers of the omission, and Renier Michiel, who explained in endnote 36 that the trifles of the Clown had been suppressed because they could not have come from Shakespeare $(1797,308)$.

\section{Conclusion}

The two contrasting translating styles which emerged from this analysis reflect different visions of both literary language and taste, confirming the influence that the target cultural system exercises on every translator (Brake, Walker and Walker 1995, 29). Le Tourneur shaped the Shakespearean source text according to the literary fashion of his own time. Since the rules of le beau langage (the beautiful language) were considerate of the readers' preferences and 'the reader 'makes' literature no less than the writer" (Venturi 2009, 345), Le Tourneur gave Shakespeare a different voice. He did not act as a passive servant of the source text/culture but as a guide (Levy 2000, 127), which affected his philological approach to the translation. He managed to satisfy readers who wanted novelty and sensation, but "who preferred the grosser elements of life to be exactly as he had made them: discreetly segregated from the public gaze" (Pemble 2005, 86). It can be said that Le Tourneur broke the implicit contract between the source (the husband) and the target text (the wife) ${ }^{24}$ and reversed the balance of power between original text and translation (Chamberlain 1988, 456).

In Italy, Leonardo Bruni's De Interpretatione Recta (On the correct way to translate), published in 1420, was the first theoretical treatise on translation. He stressed the pivotal concept of the translator's responsibility towards his/her readers and towards the author of the

\footnotetext{
${ }^{24}$ As Chamberlain noticed, Les belles infidèles sexualized translation and brought to the surface the "cultural complicity between the issue of fidelity in translation and in marriage" (Chamberlain 1988, 456): the translation is always guilty of infidelity, while no blame can be put on the original.
} 
source text. Since a good translator conforms to the author's style, Bruni introduced the philological respect for the source text as one of the criteria to be followed in translation (Zaharia 2014, 15). Renier Michiel's approach and philological interest seems to be aligned with Bruni's theory on translation, but also with Cassoli's treatise. ${ }^{25}$ In light of her acquaintance with the translation debate of her time, revealed in her preface, it is not unreasonable to assume that Renier Michiel was aware of the consequences of Le Tourneur's approach to translation. ${ }^{26}$ Renier Michiel was scrupulous ${ }^{27}$ in understanding the features of the source text as in having a clear idea of the shifts in the French translation. This proves she fully grasped the way cultural differences could influence the translation approach and the final result.

The primacy of Renier Michiel's Othello as the first Italian translation of the play should make it worthy of extensive critical consideration. Moreover, it is part of one of the most ambitious attempts of women's translation in Italy. In this sense, the documentary value of prefaces in women's writing and translation is once more confirmed. Renier Michiel had a direct channel to communicate her critical thoughts as a reader and as a cultured woman, which helps to reconstruct Shakespeare's reception in Italy from a different perspective. Her preface also brings to light the personal motivations which characterized Italian women's writing. British writers such as the already mentioned Margaret Tyler or Aphra Behn, for instance, aimed at challenging the social prejudice on women and the disparity of treatment in their education with a discourse that did not refer overtly to private or personal experience (Tyler 2014; Todd 1993). The scarce accounts on the reception of Renier Michiel's translation do not allow verifying whether her personal educational purpose as a mother and her direct reference to a female audience might have negatively influenced the cold critical reception of her contemporaries.

\footnotetext{
${ }^{25}$ Francesco Cassoli's Ragionamento sulle traduzioni poetiche (Thoughts on the translation of poetry) (published posthumously in 1826) analyzed the proper critical approach to translation. According to Cassoli, a confrontation between source text and target text was indispensable to detect shifts or unnecessary additions (Laurenti 2015, 180).

${ }^{26}$ Le Tourneur (1776, cxxxv) defined his translation of Othello as "exact et vraiment fidèle" (exact and faithful), "une copie ressemblante" (a copy resembling the original) and "as toujours rigoureusement littèrale" (as always, rigorously literal). As Delabastita stated, however, the result fell short of expectations: "On the stylistic level especially, Le Tourneur's professed tolerance for Shakespeare's peculiarities and faults remained largely theoretical" (Delabastita 1993, 338).

${ }^{27}$ The correspondence she kept with Don Sante Della Valentina proved the amount of research when writing Origine delle Feste Veneziane (Origin of the Venetian holidays), published in French in four volumes between 1817 and 1827.
} 
Gender bias certainly discouraged a more detailed analysis of Renier Michiel's work. On the one hand, critics gave Cesarotti almost full credit for the final outcome; on the other, Renier Michiel's work was underestimated and critically dismissed as an indirect translation through the French edition. These two positions are contradictory, because, if both true, the highly estimated Cesarotti would have authored a modest indirect translation from the French. They also deprive Renier Michiel of any voluntary and active influence on the target text. As to the first critical position, the style of Cesarotti's translations was proven incompatible with the qualities displayed by Renier Michiel's target texts. As to the second critical position, the relevant stylistic differences between the Italian target text and Le Tourneur's translation contradict the hypothesis that Renier Michiel's Otello was an indirect translation. The analysis brought to light that the English edition was more than an occasional support source. Renier Michiel kept the English source text in high consideration and approached her translation with scrupulous philological attention. The wide range of cases in which she referred to Pope's edition of Shakespeare's plays strengthens the idea that providing a translation as close to the source text as possible was one of her goals. Whenever the intention to ensure a high stylistic standard forced her to deviate from the English source text, she provided direct translations in endnotes to give the most precise idea possible of the content of the play.

Renier Michiel's solutions, in fact, aim at producing a natural-sounding line in Italian. Her translating choices were often more effective and fluent than Le Tourneur's: the French translator is "molto meno conciso della Renier Michiel, senza dire molto di più, né meglio" (Crinò 1950, 49; far less concise than Renier Michiel, without saying something more nor in a better way; my translation). Whether she was aware of it or not, Renier Michiel certainly tried to capture one of the key features of the Shakespearean text: the ability to communicate efficiently by selecting and organizing the words accordingly, without lengthening the lines and losing their performative essence (Brown 1962,19). This stylistic sensitivity is even more interesting considering that Renier Michiel's translations were not meant to be (and were not) performed.

It can be argued that Reiner Michiel's translation approach and strategies illustrate a woman translator's struggle for double agency: she strived to exercise her agency as a woman and as a translator. The struggle was complex and two-layered. She struggled to transgress the boundaries imposed on women by getting involved in her daughter's education through 
transLogos 2019 Vol 2 Issue 2

translation. At the same time, she struggled to use her agency as a (woman) translator by deploying a variety of translation strategies and choosing among them in accordance with her own translation aim and agenda, which can be argued to show that her translation was much more than a mere indirect translation from Le Tourneur.

It emerges that Renier Michiel's contribution to the knowledge of Shakespeare in Italy was as significant as that of men translators that had faced the challenge before her, but her translations still await the proper critical recognition. 


\section{References}

Alonge, Roberto. 1988. Teatro e spettacolo nel secondo ottocento [Theatre and performance in the second half of the 19th century]. Bari: Laterza.

Baer, Brian James, and Francoise Massardier-Kenney. 2015. "Gender and Sexuality." In Researching Translation and Interpreting, edited by Claudia V. Angelelli and Brian James Baer, 83-96. London: Routledge.

Barker, Anna. 2011. "Helen Maria William's Paul and Virginia." In Translating Women, edited by Luise von Flotow, 57-70. Ottawa: University of Ottawa Press.

Bassnett, Susan. 2005. "Translation, Gender and Otherness." Perspectives: Studies in Translatology 13 (2): 83-90. doi:10.1080/09076760508668976.

Bianco, Francesca. 2017. "Shakespeare: Le traduzioni veneziane di Giustina Renier Michiel e Melchiorre Cesarotti." [Shakespeare: The Venetian translations by Giustina Renier Michiel and Melchiorre Cesarotti.] In L'Italianistica oggi: Ricerca e didattica; Atti del XIX Congresso dell'ADI - Associazione degli Italianisti (Roma, 9-12 Settembre 2015) [Italianistic today: Didactics and research; Proceedings of the XIX ADI (Italianist Association) Congress (Rome, 9-12 September 2015)], edited by Beatrice Alfonzetti, Teresa Cancro, Valeria Di Iasio, and Ester Pietrobon, 1-10. Rome: Adi Editore.

Brake, Terence, Danielle Medina Walker, and Thomas D. Walker. 1995. Doing Business Internationally: The Guide to Cross-Cultural Success. Burr Ridge: Irwin.

Brown, John Russell. 1962. Shakespeare and His Comedies. London: Methuen.

Butterfield, Ardis. 2000. "National Histories." In Cultural Reformations: Medieval and Renaissance in Literary History, edited by Brian Cummings and James Simpson, 3355. New York: Oxford University Press.

Calvani, Alessandra. 2010. "Le donne in traduzione: Le traduttrici di Shakespeare dal 1798 al primo decennio fascista." [Women in translation: Women translators of Shakespeare from 1798 to the first Fascist decade.] inTRAlinea 12. http://www.intralinea.org/archive/article/1657.

2012. Traduzioni e traduttori: Gli specchi dell'originale [Translations and translators: The mirrors of the original]. Padova: Libreria Universitaria Edizioni.

- 2017. "Key Cultural Texts in Translation: Shakespeare and Sterne in Italy." Journal of Italian Translation 12 (2): 16-37.

Chamberlain, Lori. 1988. "Gender and the Metaphorics of Translation." Signs 13 (3): 454472. 
Chemello, Adriana. 2010. "Fuori dai repertori: Donne sulla scena letteraria ottocentesca." [Far from the inventory: Women on the 19th century literary scene.] Dimensioni e problemi della ricerca storica 1 (January-June): 45-60. doi:10.7376/70329.

Collison-Morley, Lacy. 1916. Shakespeare in Italy. Stratford-Upon-Avon: Shakespeare Head Press.

Contorbia, Franco, ed. 2006. Lucia Morpurgo Rodocanachi: Le carte, la vita [Lucia Morpurgo Rodocanachi: Her letters, her life]. Firenze: Società Editrice Fiorentina.

Cox, Virginia. 2008. Women's Writing in Italy: 1400-1650. Baltimore: John Hopkins University Press.

Crinò Annamaria. 1950. Le traduzioni di Shakespeare in Italia nel settecento [The translations of Shakespeare in Italy in the 18th century]. Rome: Edizioni di Storia e Letteratura.

Crotti, Ilaria. 2005. "Presenze traslate: Giustina Renier Michiel nelle lettere di Melchiorre Cesarotti." [A shifted presence: Giustina Renier Michiel in Melchiorre Cesarotti's letters.] In Sentir e meditar: Omaggio a Elena Sala Di Felice [Sentir e Meditar: Homage to Elena Sala Di Felice], edited by Laura Sannia Nowé, Roberto Puggioni, and Francesco Cotticelli, 227-242. Rome: Aracne.

Cushing, Mary Gertrude. 1908. Pierre Le Tourneur. New York: Columbia University Press.

Delabastita, Dirk. 1993. There's a Double Tongue: An Investigation into the Translation of Shakespeare's Wordplay, with Special Reference to Hamlet. Amsterdam: Rodopi.

Fois, Eleonora. 2018. Shakespeare tradotto: Le opere del Bardo in Italia fra testi e scena [Shakespeare translated: The works of the Bard between text and stage in Italy]. Rome: Carocci.

Goodfellow, Sarah. 1996. "'Such Masculine Strokes': Aphra Behn as Translator of $A$ Discovery of New Worlds." Albion: A Quarterly Journal Concerned with British Studies 28 (2): 229-250. doi:10.2307/4052460.

Graf, Arturo. 1911. L'anglomania e l'influsso inglese in Italia nel secolo XVIII [Anglomania and the English influence in 18th century Italy]. Torino: E. Loescher.

Hamburger, Mick. 2004. “'If It Be Now': The Knocking of Fate; Reading Shakespeare for Translation." In Translating Shakespeare for the Twenty-first Century, edited by Rui Carvalho Homem and Ton Hoenselaars, 117-129. Amsterdam: Rodopi.

Hoenselaars, Ton. 2003. "Shakespeare and Translation." In Shakespeare: An Oxford Guide, edited by Stanley Wells and Lena Cowen Orlin, 645-657. Oxford: Oxford University Press. 
transLogos 2019 Vol 2 Issue 2

Fois, Eleonora, pp. 134-158

Hulme, Hilda M. 1962. Explorations in Shakespeare's Language: Some Problems of Lexical Meaning in the Dramatic Text. London: Longmans.

Jones, Verina R. 2000. “Journalism, 1750-1850.” In A History of Women's Writing in Italy, edited by Letizia Panizza and Sharon Wood, 120-134. Cambridge: Cambridge University Press.

Kemp, Theresa D. 2010. Women in the Age of Shakespeare. Denver: Greenwood Press.

Laurenti, Francesco. 2015. Tradurre: Storie, teorie, pratiche dall'antichità al XIX secolo [Translation: History, theories and practice from the ancient times to the 19th century]. Rome: Armando Editore.

Le Tourneur, Pierre, trans. 1776. Shakespeare traduit de l'anglois, dédié au roi. Tome premier [Shakespeare translated from English, dedicated to the King. First volume]. Paris: Chez La Veuve Duchesne.

Levy, Anthony. 2000. "Belles Infidèles." In Encyclopedia of Literary Translation into English: A-L, edited by Olive Classe, 126-127. Chicago: Fitzroy Dearborn Publishers.

Locatelli, Angela. 1999. "Shakespeare in Italian Romanticism: Literary Querelles, Translations, and Interpretations." In Shakespeare and Italy, edited by Holger M. Klein and Michele Marrapodi, 10: 19-37. Lewinston: Edwin Mellen Press.

Lombardo, Agostino. 1964. "Shakespeare e la critica italiana." [Shakespeare and the Italian critics.] Sipario 218 (June): 2-13.

1997. "Shakespeare in Italy." Proceedings of the American Philosophical Society 141 (4): 454-462. www.jstor.org/stable/987221.

Lotman, Yuri M. 1990. Universe of the Mind: A Semiotic Theory of a Culture. London: I.B. Tauris.

Malone, Joseph L. 1988. The Science of Linguistics in the Art of Translation. Albany: State University of New York Press.

Mandelker, Amy. 2006. "Lotman's Other: Estrangement and Ethics in Culture and Explosion." In Lotman and Cultural Studies: Encounters and Extensions, edited by Andreas Schönle, 59-83. Madison: University of Wisconsin Press.

McMahon, Joseph H. 1964. "Ducis: Unkindest Cutter?” Yale French Studies, no. 33, 14-25. doi:10.2307/2929585.

Melchiori, Giorgio. 2006. Shakespeare all'opera: I drammi nella librettistica italiana [Shakespeare at the Opera. Shakespeare's works in Italian librettos]. Rome: Bulzoni Editore. 
transLogos 2019 Vol 2 Issue 2

Fois, Eleonora, pp. 134-158

trans Dogos

A Translation Studies Journal

Shakespeare Translated by a Woman:

Giustina Renier Michiel's Othello

(C) Diye Global Communications diye.com.tr|diye@diye.com.tr

Messbarger, Rebecca, and Paula Finden, eds. 2005. The Contest for Knowledge: Debates over Women's Learning in Eighteenth-Century Italy. Chicago: University of Chicago Press.

Munday, Jeremy. 2007. "Translation and Ideology: A Textual Approach." The Translator 13 (2): 195-217. doi:10.1080/13556509.2007.10799238.

Peletier du Mans, Jacques. 1555. L'Art Poetique de Jacques Peletier du Mans [The poetic art of Jacques Peletier du Mans]. Lyon: Ian de Tournes \& Guil. Gazean.

Pemble, John. 2005. Shakespeare Goes to Paris: How the Bard Conquered France. New York: Hambledon and London.

Petrone Fresco, Gabi. 1993. Shakespeare's Reception in 18th Century Italy: The Case of Hamlet. Bern: Peter Lang.

Quasimodo, Salvatore, Vico Cesare Lodovici, Gabriele Baldini, and Mario Praz. 1964. "Il problema della traduzione." [The problem of translation.] Sipario 218 (June): 16-20.

Rebora, Pietro. 1949. "Comprensione e Fortuna di Shakespeare in Italia." [Reception and fortune of Shakespeare in Italy.] Comparative Literature 1 (3): 210-224. doi:10.2307/1769169.

Renier Michiel, Giustina, trans. 1797. Opere drammatiche di Shakspeare volgarizzate da una Cittadina Veneta. Tomo I [Dramatic works by Shakespeare translated into vernacular by a Venetian citizen. Book I]. Venice: Eredi Costantini.

Ritchie, Fiona. 2014. Women and Shakespeare in the Eighteenth Century. New York: Cambridge University Press.

Roberts, Rachel. 2017. "Englishing A Spanish Romance Translating Spanish Rivalry into English Patriotism in Margaret Tyler's Mirror of Princely Deeds and Knighthood." inTRAlinea 19. http://www.intralinea.org/archive/article/2264.

Russell, Rinaldina, ed. 1997. The Feminist Encyclopedia of Italian Literature. Westport, Conn.: Greenwood Press.

Semenenko, Aleksei. 2012. The Texture of Culture: An Introduction to Yuri Lotman's Semiotic Theory. New York: Palgrave Macmillan.

Serpieri, Alessandro. 1988. Nel laboratorio di Shakespeare: Il quadro teorico [Into Shakespeare's workshop: The theoretical framework]. Parma: Pratiche Editrice.

Shakespeare, William. 1768. The Works of Shakespear, from Mr. Pope's Edition. Volume the Ninth. Containing, Troilus and Cressida. Romeo and Juliet. Hamlet. Othello. Birmingham: Robert Martin. 
Stavinschi, Alexandra C. 2012. "Pragmatic Markers in Translation." In The Translation of Fictive Dialogue, edited by Jenny Brumme and Anna Espunya, 233-249. Amsterdam: Rodopi.

Stewart, Pamela D. 1994. "Luisa Bergalli (1703-1779)." In Italian Women Writers: A Biobibliographical Sourcebook, edited by Rinaldina Russell, 50-57. Westport, Conn.: Greenwood Press.

Todd, Janet, ed. 1993. The Works of Aphra Behn. Vol. 4, Seneca Unmasqued and Other Prose Translations. London: W. Pickering.

Tyler, Margaret. 2014. Mirror of Princely Deeds and Knighthood. MHRA Tudor \& Stuart Translations, vol. 11, edited by Joyce Boro. London: Modern Humanities Research Association.

Venturi, Paola. 2009. "The Translator's Immobility: English Modern Classics in Italy." Target 21 (2): 333-357. doi:10.1075/target.21.2.06ven.

Walton, Michael. 2008. “An Agreeable Innovation': Play and Translation.” In Translation and the Classic: Identity as Change in the History of Culture, edited by Alexandra Lianeri and Vanda Zajko, 261-276. Clarendon: Oxford University Press.

Waring, Caroline. 2007. "Laura Terracina's Feminist Discourse (1549): Answering the Furioso." In Investigating Gender, Translation and Culture in Italian Studies, edited by Monica Boria and Linda Risso, 151-167. Leicester: Troubador.

Zaharia, Oana-Alis. 2014. “De interpretatione recta...': Early Modern Theories of Translation." American, British and Canadian Studies Journal 23 (1): 5-23. doi:10.1515/abcsj-2014-0024. 